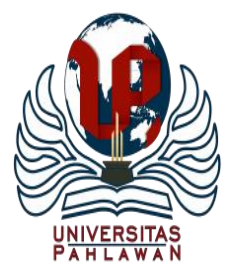

Edukatif : Jurnal Ilmu Pendidikan Volume 3 Nomor 4 Tahun 2021 Halm 1220 - 1230

EDUKATIF: JURNAL ILMU PENDIDIKAN

Research \& Learning in Education

https:/ledukatif.org/index.php/edukatif/index

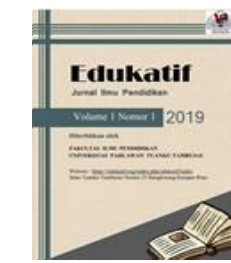

\title{
Pengembangan Permainan Ular Tangga Kimia Berbasis Android Sebagai Media Pembelajaran pada Materi Senyawa Hidrokarbon di Sekolah Menengah Atas
}

\author{
Yurnalisa Aprilia ${ }^{1 凶}$, Iswendi $^{2}$ \\ Universitas Negeri Padang, Indonesia ${ }^{1,2}$ \\ E-mail : yurnalisaaprilia@gmail.com ${ }^{1}$, iswendy956@gmail.com ${ }^{2}$
}

\begin{abstract}
Abstrak
Penelitian ini bertujuan untuk menghasilkan produk berupa permainan ular tangga kimia berbasis android sebagai media pembelajaran pada materi senyawa hidrokarbon serta menentukan tingkat validitas berdasarkan fungsi media. Jenis penelitian yang digunakan adalah development studies dengan model Plomp yang terdiri dari tiga tahap, yaitu tahap preliminary research, prototypingstage, dan assessmentphase. Penelitian ini dibatasi sampai tahap prototypingstage yaitu tahap penilaian ahli (expertreview). Instrumen penelitian yang digunakan adalah angket validasi yang diberikan kepada dua orang dosen kimia UNP dan dua orang guru kimia SMAN 2 Sawahlunto. Teknik pengumpulan data yang digunakan dengan penyebaran angket kemudian dianalisis menggunakan Aiken's V. Hasil analisis data diperoleh bahwa permainan ular tangga kimia berbasis android sebagai media pembelajaran pada materi senyawa hidrokarbon memiliki tingkat validasi sebesar 0,86 dengan kriteri valid. Hasil penelitian ini menunjukkan bahwa permainan ular tangga kimia yang dikembangkan sudah valid sebagai media pembelajaran pada materi senyawa hidrokarbon kelas XI sekolah menengah atas.
\end{abstract}

Kata Kunci: ular tangga kimia berbasis android, Senyawa Hidrokarbon, Development studies.

\begin{abstract}
This research aim to produce of Chemical ladder snake game based on Android as Learning media on Hydrocarbon compound with determine level ofvalidation as a media. This type of research is development studies use Plomp model which is consist of three steps, they are preliminary research, prototyping stage, and assessment phase. This research is limited to prototyping stage whice is used assessment phase by expert review. Instrument used was a validity questionnaire given to two UNP chemistry lecturers and two chemistry teachers at SMAN 2 Sawahlunto. Data collection techniques deplopment questionnaire were analyzed by Aiken's. The result of data analysis showed that Learning media of Chemical ladder snake game based on Android used Hydrocarbon compound found that the level of validation was 0,86. The result of research showed that Chemical ladder snake game was valid as a learning media on Hydrocarbon compound in class of XI senior hight school.
\end{abstract}

Keywords:chemicalladdersnakegame, hydrocarboncompound, development studies, model plom.

Copyright (c) 2021 Yurnalisa Aprilia, Iswendi

$\triangle$ Corresponding author

Email : yurnalisaaprilia@gmail.com

DOI : https://doi.org/10.31004/edukatif.v3i4.548

ISSN 2656-8063 (Media Cetak)

ISSN 2656-8071 (Media Online)

Edukatif : Jurnal Ilmu Pendidikan Vol 3 No 4 Tahun 2021 p-ISSN 2656-8063 e-ISSN 2656-8071 
1221 Pengembangan Permainan Ular Tangga Kimia Berbasis Android Sebagai Media Pembelajaran pada Materi Senyawa Hidrokarbon di Sekolah Menengah Atas - Yurnalisa Aprilia, Iswendi

DOI: https://doi.org/10.31004/edukatif.v3i4.548

\section{PENDAHULUAN}

Materi pokok yang diajarkan pada kelas XI SMA salah satunya adalah materi senyawa hidrokarbon yang berisi pengetahuan faktual, konseptual, dan prosedural. Dalam pemenuhan pemahaman isi dari materi ini, diperlukan kegiatan membaca, diskusi dan pengerjaan latihan yang lebih banyak. Untuk meningkatkan pemantapan konsep peserta didik mengenai pengetahuan faktual, konseptual, dan prosedural yang telah dipelajari maka perlu dilakukan latihan (Febriani \& Ellizar, 2019).

Observasi yang dilakukan dengan pemberian angket terhadap masing-masing satu orang guru kimia di SMAN 2 Sawahlunto, SMAN 7 Padang, dan SMAN 13 Padang dapat diketahui pada materi senyawa hidrokarbon guru menggunakan modul, buku teks, lembar kerja peserta didik (LKPD), powepoint, dan gambar. Guru selalu memberikan latihan untuk memantapkan konsep peserta didik yang bersumber dari buku teks, LKPD, dan buku kumpulan soal. Kurangnya semangat peserta didik dan masih ada peserta didik yang mencontek saat mengerjakan latihan dalam pembelajaran. Untuk memantapkan konsep mendorong motivasi belajar, dan mengembangkan kemampuan berpikir peserta didik untuk memberikan solusi terhadap masalah yang dihadapi mengenai materi yang diajarkan diperlukan latihan yang efektif (Hamalik, 2017).

PAIKEM (Pembelajaran Aktif, Interaktif, Kreatif, Efektif dan Menyenangkan) adalah proses belajar yang mengharuskan individu dapat mengembangkan, memahami, dan memantapkan konsep pembelajaran. Sementara guru menggunakan media dan sumber belajar yang inovatif, menarik, dan efektif sehingga menambah keaktifan peserta didik (Haryono, 2013). Peserta didikusi tujuh sampai delapan belas tahun cenderung menyukai permainan dalam kegiatan pembelajaran, termasuk latihan dalam bentuk permainan (Yolanda \& Iswendi, 2019). Pembelajaran melalui permainan memiliki beberapa keunggulan yaitu menyenangkan, menghibur, dan permainan mengajak peserta didik untuk aktif belajar sehingga terasa menyenangkan. Permainan dapat berperan dalam mengaktifkan peserta didik dalam proses belajar mengajar (Indriliza L \& Iswendi, 2019).

Permainan dapat mengurangi kebosanan walaupun penggunaannya berulang-ulang (Haryono, 2013). Materi kimia seperti senyawa hidrokarbon memiliki banyak pengetahuan faktual, konseptual dan prosedural sehingga cocok digunakan media permainan. Permainan yang digunakan dapat sebagai media pembelaran ataupun media untuk latihan. Salah satu permainan yang dapat dikembangkan dapat berupa permainan ular tangga kimia berbasis android. Media ini diisi banyak soal. Hal ini dapat dijadikan alternatif prngganti model latihan. Media ini dilengkapi gambaran isi materi berupa fakta dan konsep sehingga membantu peserta didik mengingat isi materi yang dipelajari.

Untuk meningkatkan hasil belajar peserta didik dapat digunakan permainan sebagai salah satu alternatif media pembelajaran. Menurut penelitian yang dilakukan pada materi hidrokarbon penggunaan permainan ular tangga dapat meningkatkan prestasi belajar sebesar 16,84\% (Rahmadani, 2015). Terdapat kesamaan pada penggunaan materi dengan penelitian Rahmadani, namun perbedaan terlihat dari media yang digunakan yakni Rahamadani menggunakan media ular tangga biasa sedangkan penelitian ini berbasis Android. Selain itu, permainan ular tangga pada materi hidrokarbon juga dapat meningkatkan aktivitas dan efektivitas siswa berdasarkan pemahaman konsep siswa dengan skor N-gain 0,7 (Paramita, 2016). Begitu juga dengan penelitian media permainan ular tangga berbasis android pokok bahasan gejala pemanasan global untuk pembelajaran fisika di SMA efektif dalam meningkatkan hasil belajar peserta didik dengan skor $\mathrm{N}$-gain sebesar 0,73 (Guterres, 2018). Terdapat kesamaan media yang digunakan yakni berbasis Android akan tetapi terdapat perbedaan pada materi yang digunakan yakni gluterres menggunakan materi pembelajaran fisika dan penelitian ini menggunakan materi kimia. Dengan demikian penelitian ini terjaga originalitasnya dari penelitian sebelumnya.

Kondisi pandemi mengharuskan proses pembelajaran tidak dilakukan dengan tatap muka. Oleh karena itu, guru diharapkan dapat mengimplementasikan teknologi informasi dan komunikasi di dalam belajar 
1222 Pengembangan Permainan Ular Tangga Kimia Berbasis Android Sebagai Media Pembelajaran pada Materi Senyawa Hidrokarbon di Sekolah Menengah Atas - Yurnalisa Aprilia, Iswendi

DOI: https://doi.org/10.31004/edukatif.v3i4.548

mengajar. Alternatif yang dapat digunakan dalam keadaan pandemi adalah media pembeljaran ular tangga kimia berbasis android. Aplikasi ini dapat digunakan dimana saja karena produknya yang efisien dibandingkan ular tangga manual yang membutuhkan tempat dan koordinator dalam pelaksanaanya.

Berdasarkan penjabaran tersebut dikembangkan media pembelajaran berupa permainan ular tangga kimia berbasis android sebagai media pembelajaran sebagai salah satu alternatif pemantapan konsep peserta didik, maka dari itu dilakukan penelitian dengan judul "Pengembangan Permainan Ular Tanga Kimia Berbasis Android sebagai Media Pembelajaran pada Materi Senyawa Hidrokarbon di Sekolah Menengah Atas”

\section{METODE}

Penelitian yang dilakukan adalah development studies menggunakan model Plomp yang dikembangkan oleh Tjeerd Plomp. Model pengembangan Plomp terdiri dari tiga tahap, yaitu tahap investigasi awal, tahap pembentukan konsepdan tahap penilaian (Plomp, 2013). Proses penelitian yang dilakukan hanya sampai tahap pembentukan konsep yaitutahap peniaian ahli.

Kegiatan penelitian dilakukan di FMIPA UNP dan SMAN 2 Sawahlunto pada semester januari-juni 2021. Subjek penelitian adalah dosen kimia FMIPA UNP dan guru kimia SMAN 2 Sawahlunto. Objek penelitian adalah media pembelajaran berupa permainan ular tangga kimia berbasis android pada materi senyawa hidrokarbon untuk kelas XI SMA/MA.Instrumen yang digunakan dalam penelitian ini berupa angket validasi dengan teknik analisis data aiken's v.

\section{HASIL DAN PEMBAHASAN}

Analisis kebutuhan. Analisis ini bertujuan untuk mengetahui bagaimana penerapan latihan sebagai pemantapan konsep peserta didik pada materi senyawa hidrokarbon, dengan melakukan wawancara dengan guru kimia di tiga sekolah tingkat SMA/MA. Analisis konteks dilakukan kegiatan menelaah kurikulum yang digunakan yaitu kurikulum 2013. Indikator pencapaian kompetensi dapat diturunkan berdasarkan kompetensi dasar materi senyawa hidrokarbon.

Studi literature. Pembelajaran dapat lebih menarik motivasi peserta didik jika digunakan perantara media. Hal ini memungkinkan individu lebih mudah paham dan proses belajar mengajar jadi lebih efektif dan efisien (Musfiqon, 2012). Sejalan dengan penelitian terdahulu yang menyatakan media pembelajaran dapat digunakan sebagai variasi latihan untuk meningkatkan hasil belajar, seperti media permainan ular tangga berbasis android, media permainan kartu UNO, media berbasis fun chemistry blog (Guterres, 2018; Normadana, 2018; Sari, Y., dkk, 2018).

Permainan ular tangga sangat dikenal di seluruh dunia. Berdasarkan hasil penelitian menunjukkan pengembangan media permainan ular tangga kimia berbasis android sangat efektif dalam proses pembelajaran seperti pada penelitian yang dilakukan oleh (Murti, 2017).

Produk yang dikembangkan berupa permainan ular tangga kimia berbasis android pada materi senyawa hidrokarbon. Materi tersebut berisi pengetahuan faktual, konseptual, dan prosedural sehingga materi tersebut diperlukan suatu usaha salah satunya mengerjakan latihan. Berdasarkan penelitian yang telah dilakukan mengenai media pembelajaran pada materi Senyawa Hidrokarbon berupa media permaianan kartu UNO (Sari, Y., dkk, 2018), permainan ular tangga (Rahmadani, 2015), dan media game (Sumadi, 2015).

Pengembangan kerangka konseptual. Pada tahap pengembangan kerangka konseptual dilakukan pengidentifiksi, perincian dan penyusunan dari analisis kebutuhan, konteks, serta studi literatur. Berdasarkan analisis kebutuhan, peserta didik memerlukan sebagai evaluasi pembelajaran untuk pemantapan konsep. Dalam mengerjakan latihan, peserta didik tentunya harus memiliki motivasi agar aktivitas belajar dapat meningkat. Untuk itu diperlukan suatu latihan yang bervariasi agar pembelajaran tidak membosankan. Salah 
1223 Pengembangan Permainan Ular Tangga Kimia Berbasis Android Sebagai Media Pembelajaran pada Materi Senyawa Hidrokarbon di Sekolah Menengah Atas - Yurnalisa Aprilia, Iswendi

DOI: https://doi.org/10.31004/edukatif.v3i4.548

satu variasi latihan yaitu dengan menggunakan permainan. Sehingga diciptakan suatu produk berupa permainan ular tangga kimia berbasis android sebagai pilihan dalam pengerjaan soal untuk pemantapan konsep peserta didik.

Tahap pembentukan konsep (prototyping stage).Prototyping I. Prototipe 1 merupakan perancangan produk berdasarkan data yang diperoleh dari tahap investigasi awal (preliminary research). Prototipe 1 menghasil permainan ular tangga kimia berbasis android pada materi senyawa hidrokarbon. Permainan ini ditampilkan dalam bentuk aplikasi, di dalam permainan ini terdiri dari, cover, aturan permainan, identias pemain, papan permainan, dan halaman pemenang. Permainan ini dirancang menggunakan metode perancangan aplikasi waterfall. Metode waterfall terdapat 5 tahap yaitu analisis kebutuhan (Requirement), desain sistem (design system), penulisan kode program atau implementation (coding and testing), penerapan dan pengujian program (integration and testing), pemeliharaan (opration and maintenance).

Cover

Sampul depan/cover yang ditampilkan berisi judul, materi yang di sajikan, dan gambar ular tangga. Cover yang digunakan dominan berwarna biru yang tidar terlalu terang atau gelap. Penggunaan warna biru pada media yang rancang memberikan kesan kedamaian dan kenyamanan. Gradasi warna biru dapat menenangkan mata, damai, dan relax (Purbasari, 2014). Pemilihan warna biru dapat meningkatkan ketertarikan peserta didik dalam menggunakan permainan. Cover permainan dapat dilihat pada Gambar 1 .

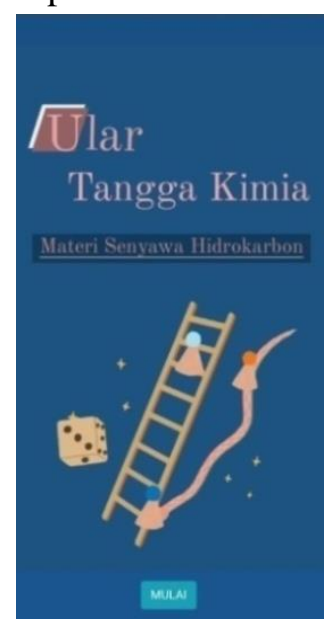

Gambar 1. Cover permainan

Peraturan permainan terdiri dari petunjuk penggunaan untuk guru dan peserta didik. Peraturan ini diberikan agar guru dan peserta didik mengetahui cara penggunaan permainan ular tangga kimia berbasis android dalam pembelajaran. Pada petunjuk diberikan informasi mengenai aturan jumlah pemain, langkah langkah bermain dan aturan pengskoran dalam bermain. Aturan permainan dapat dilihat pada Gambar 2. 
1224 Pengembangan Permainan Ular Tangga Kimia Berbasis Android Sebagai Media Pembelajaran pada Materi Senyawa Hidrokarbon di Sekolah Menengah Atas - Yurnalisa Aprilia, Iswendi

DOI: https://doi.org/10.31004/edukatif.v3i4.548

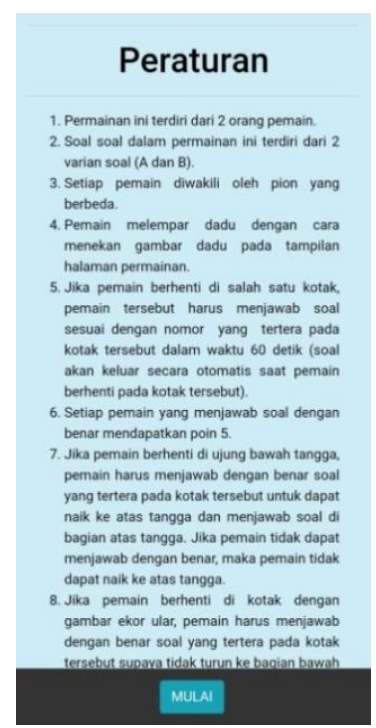

Gambar 2. Aturan permainan

Papan permainan ular tangga kimia terdiri dari 36 kotak dengan kotak pertama start untuk memulai permainan, kotak terakhir finish untuk mengakhiri permainan, dan kotak selain itu diberi nomor. Kotak pada papan permainan diberikan gambar pengetahuan faktual dan pengetahuan konseptual yang berfungsi untuk membantu peserta didik dalam menjawab soal-soal yang terdapat dalam permainan. Di bagian bawah terdapat dadu dan papan skor pemain, dan di bagian atas papan permainan terdapat waktu bermainan dan apabila waktu telah habis dan permainan belum selesai maka pemain dengan skor tertinggi adalah pemenang. Gambar papan permainan disajikan pada Gambar 3.

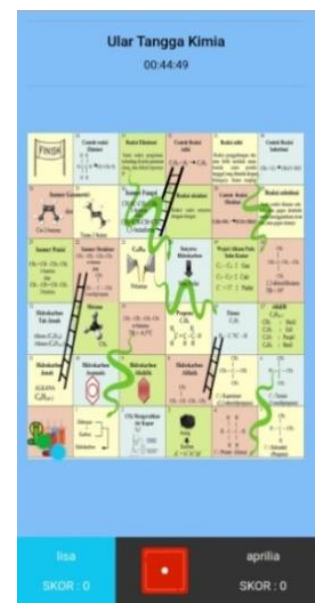

Gambar 3. Halaman permainan

Halaman pemenang merupakan salah satu komponen permainan ular tangga kimia berbasis android yang ditampilkan pada prototipe 1. Hasil dari permainan pada halaman sebelumnya akan ditampilkan pada halaman ini. Pada halaman pemenang terdapat skor masing masing pemain dan pemain yang jumlah skor tertingi akan dinyatakan sebagai pemenang dalam permaian. gambar halaman pemenang disajikan pada Gambar 4. 


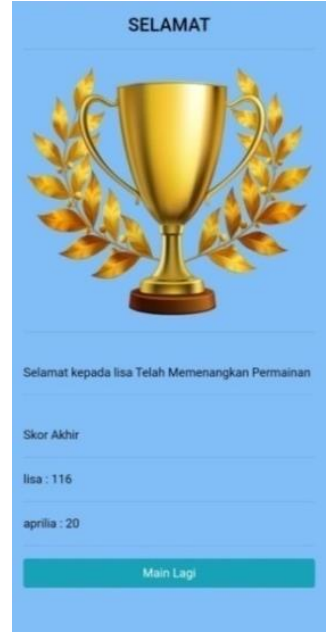

Gambar 4. Halaman pemenang

Prototyping II. Pada prototipe II dilakukan selfevaluation untuk memperbaiki hasil dari prototipe I. Penilaian diri sendiri dilakukan dengan menggunakan sistem checklist pada angket. Tahap ini difokuskan pada kesalahan dalam langkah-langkah permainan seperti alur jalannya pion dan jumlah penambahan poin kepada salah satu pemain yang pertama sampai di finish.

Prototyping III. Uji coba satu-satu (one to one evaluation).Uji coba ini dilakukan oleh tiga orang peserta didik yang memiliki kemampuan berbeda. Berdasarkan hasil tersebut menujukkan bahwa prototipe III yang telah dikembangkan menurut peserta didik tampilan cover sangat menarik, jenis tulisan yang digunakan jelas dan bahasa mudah dipahami, pemilihar warna yang bagus dan menarik minat peserta didik untuk memainkannya, soal yang disajikan mudah di pahami dan sangat membantu untuk mengasah pemahaman peserta didik untuk materi senyawa hidrokarbon, dan pendapat peserta didik yang menyatakan bahwa sangat membantu dalam memantapkan konsep materi senyawa hidrokarbon.

Penilaian ahli (rexpwrt review)

Penilaian ahli (rexpert review) merupakan tahap untuk mengetahui kategori validitas permainan ular tangga kimia berbasis android materi senyawa hidrikarbon yang sudah dirancang kemudian dikembangkan dan diuji validitasnya. Untuk menilai rancangan permainan oleh validator dalam bidang kimia serta mampu memberikan masukan dan saran untuk penyempurnaan permainan. Validator menila validitas media ular tangga yang dirancang dengan memperhatikan 4 aspek, yaitu fungsi atensi, fungsi afektif, fungsi kognitif, dan fungsi kompensatoris. Pengolahan data dari hasil validasi permainan menggunakan formula Aiken's V.

Fungsi atensi media visual merupakan ketertarikan peserta didik terhadap materi yang berkaitan dengan makna visual yang ditampilkan (Arsyad, 2013). Penilaian dari validator terhadap fungsi antensi diperoleh nilai formula aiken's v 0,85 yang berkategori valid. Dengan hal ini, dapat dikatakan bahwa permainan yang dirancang mampu memotivasi peserta didik untuk memusatkan perhatian dan berkonsentrasi dalam pembelajaran materi senyawa hidrokarbon. Pada permainan ular tangga kimia berbasis android, Gambar, simbol, dan tulisan sudah jelas dan menarik bagi peserta didik. Tampilan media pembelajaran yang tidak monoton menstimulasi peserta didik guna memusatkan perhatiannya terhadap pembelajaran. Desain atau gambar-gambar yang berwarna membuat peserta didik tertarik dan menumbuhkan minatnya serta dengan diberikannya warna pada media akan merangsang impresi atau kesan realistik (Sudjana, N dan Rivai, 2011).Simbol-simbol pada permainan ular tangga kimia berbasis android sudah sesuai dengan kaidah pembelajaran kimia, seperti kotak 24 dan bentuk molekul Cis-2-butena dan trans-2-butena yang merupakan isomer geometri dari senyawa butena $\mathrm{C} 4 \mathrm{H} 8$ yaitu 2-butena dan warna molekul Hidrogen putih dan Karbon berwarna hitam. Gambar simbol dan tulisan pada ular tangga kimia berbasis android disajikan pada Gambar5. 


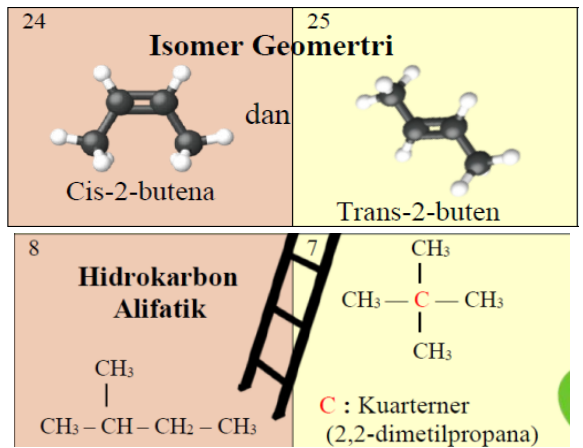

Gambar 5. Gambar simbol dan tulisan pada ular tangga kimia berbasis android

Selain itu, pemakaian jenis dan ukuran huruf yang digunakan sudah jelas. Permainan ular tangga kimia berbasis android menggunakan 3 jenis huruf yaitu pada tombol mulai menggunakan huruf bahnschrift semibold dengan ukuran $18 \mathrm{pt}$, pada aturan permainan bagian judul menggunakan huruf bahnschrift semibold denganukuran $20 \mathrm{pt}$ dan tulisan aturan permainan menggunakanarifal ukuran $12 \mathrm{pt}$, dan pada papan bermainan menggunakan huruf Times new roman dengan ukuran bervariasi seperti12 pt, 10 pt, 9 pt,dan 8 pt. Sebuah tampilan media visual sebaiknya menggunakan jenis huruf tidak lebih dari 4 macam (Febriani \& Ellizar, 2019).

Tulisan pada media harus menarik, jelas, dan mudah dibaca sehingga berfungsi menarik perhatian peserta didik, memperjelas ide, dan tidak mudah dilupakan (Daryanto, 2011). Bahasa yang terdapat pada media permainan ular tangga kimia berbasis android mudah dimengerti dan berpedoman pada Ejaan Bahasa Indonesia (EBI) yang baik dan benar. Kejelasan huruf dan penggunaan bahasa yang sesuai (EBI) pada papan permainan ular tangga kimia berbasis android disajikan pada Gambar 6.

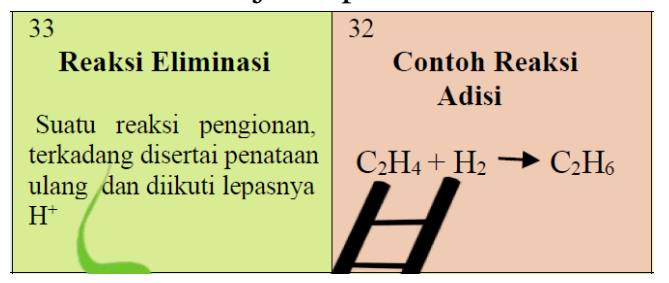

Gambar 6. Kejelasan huruf danpenggunaanbahasa yang sesuai (EBI) pada papan permainan ular tangga kimia berbasis android

Tampilan media pembelajaran yang menarik akan memberikan stimulus kepada siswa untuk memusatkan perhatiannya terhadap pembelajaran. Apabila siswa dapat memusatkan perhatiannya terhadappembelajaran maka hasil belajar individu akan meningkat seiring meningkatnya pemahaman individu (Haryono, 2013). Fungsi afektif media visual dapat terlihat dari tingkat kemapuan individu ketika belajar (membaca) teks yang bergambar (Arsyad, 2013). Penilaian yang diberikan validator terhadap fungsi afektif media pembelajaran yang dikembangkan diperoleh nilai aiken's v 0,89 dengan kriteria valid. Hal ini menunjukkan bahwa media yang dirancang dapat menarik perhatian, menyenangkan, serta dapat meningkatkan belajar peserta didik. Kelebihan permainan dalam pembelajaran menurut Iswendi and $\mathrm{R} A$ Iswara (2020), yaitu permainan dapat membuat belajar menjadi menyenangkan, tidak menekan, namun tetap kondusif. Selain itu menurut Indriliza L \& Iswendi (2019), permainan memungkinkan partisipasi aktif individu dalam belajar dan adanya unsur kompetensi dalam permainan membuat permainan menjadi lebih menarik. Desain papan permainan ular tangga kimia berbasis android disajikanpada Gambar 7. 
1227 Pengembangan Permainan Ular Tangga Kimia Berbasis Android Sebagai Media Pembelajaran pada Materi Senyawa Hidrokarbon di Sekolah Menengah Atas - Yurnalisa Aprilia, Iswendi

DOI: https://doi.org/10.31004/edukatif.v3i4.548

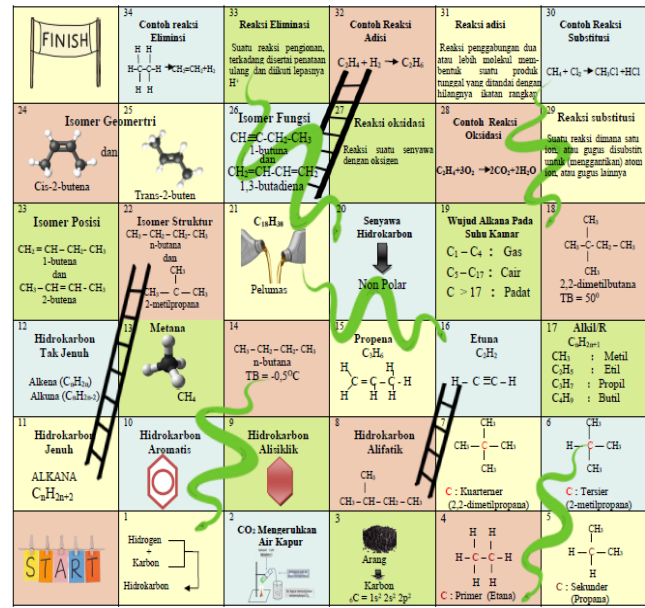

Gambar 7. Desain papan permainan ular tangga kimia berbasis android

Fungsi kognitif dapat membantu individu untuk memahami dan mengingat informasi atau pesan didalam media tersebut sehingga tujuan pembelajaran tercapai (Arsyad, 2013). Penilaian yang diberikan validator terhadap fungsi kognitif media pembelajaran yang dirancang diperoleh nilai aiken's $\mathrm{v}$ 0,89 dengan kriteria valid. Hal ini menunjukkan bahwa media yang dirancang mampu membantu individu mencapai tujuan pembelajaran, dimana soal-soal pada permainan ular tangga kimia memuat pengetahuan faktual, konseptual, dan prosedural sesuai dengan KD dan IPK materi dengan bahasa yang memudahkan pemahamannya. Hal ini sesuai dengan pernyataan (Iswendi, 2020) penggunaan media pembelajaran harus relevan dengan kompetensi dan isi materi itu sendiri. Pengetahuan faktual pada materi senyawa hidrokarbon yang terdapat pada permainan telah sesuai dengan KD 3.1, seperti yang disajikan pada Gambar 8.

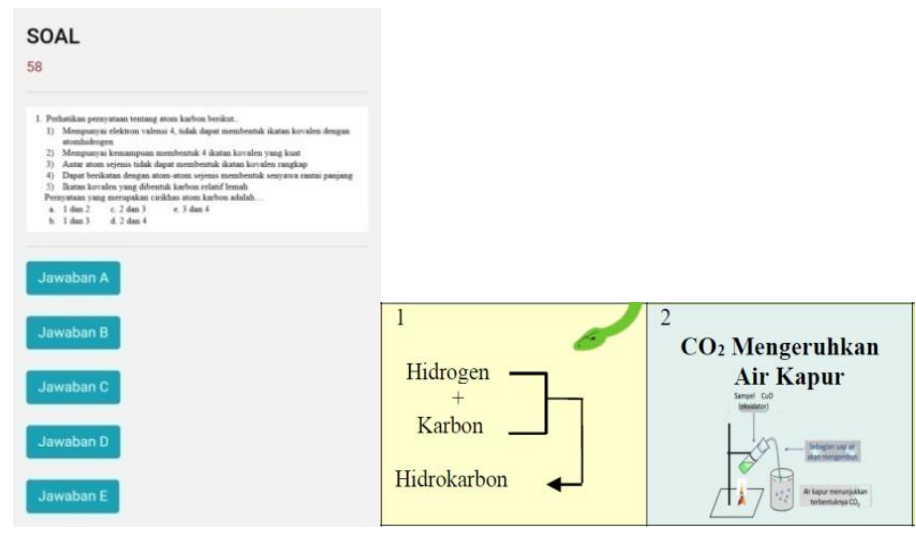

Gambar 8. Pengetahuan Faktual Pada Kartu Soal dan Papan Permainan Ular Tangga Kimia Berbasis Android

Pengetahuan konseptual yang terdapat dalam permainan telah sesuai dengan materi senyawa hidrokarbon dengan KD 3.1. seperti yang disajikan pada Gambar 9. 
1228 Pengembangan Permainan Ular Tangga Kimia Berbasis Android Sebagai Media Pembelajaran pada Materi Senyawa Hidrokarbon di Sekolah Menengah Atas - Yurnalisa Aprilia, Iswendi

DOI: https://doi.org/10.31004/edukatif.v3i4.548

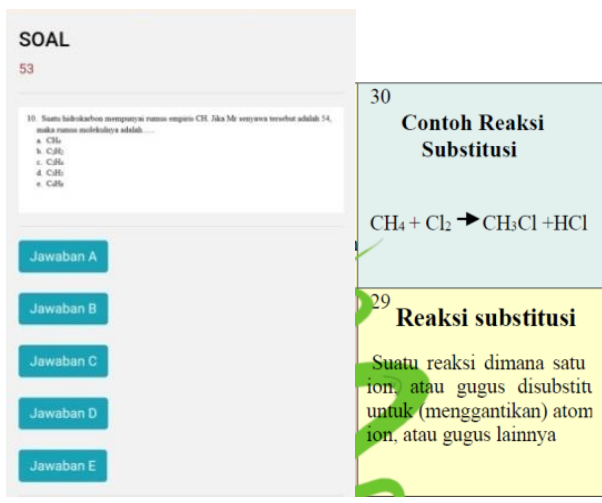

Gambar 9. Pengetahuan Konseptual Pada Kartu Soal dan Papan Permainan Ular Tangga Kimia Berbasis

Android

Pengetahuan prosedural yang terdapat pada permainan sesuai dengan KD 3.1 materi senyawa hidrokarbon, sesuai yang disajikan pada Gambar 10.

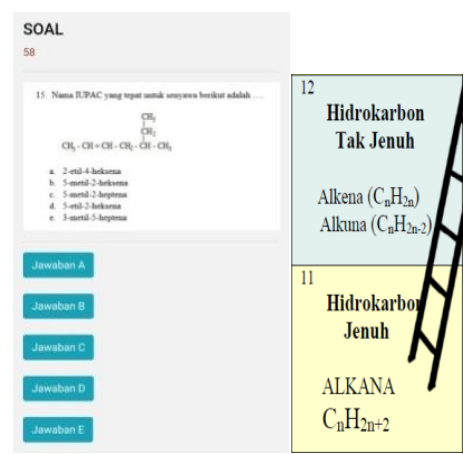

Gambar 10. Pengetahuan proseduralpada kartu soal dan papan permainan ular tangga kimia berbasis android

Fungsi kompensatoris yaitu media pembelajaran yang digunakan dengan harapan dapat membantu individu memahami materi khususnya bagi individu yang lemah (Arsyad, 2013). Berdasarkan penilaian validator diperoleh nilai aiken's v 0,83 dengan kriteria valid. Hal ini membuktikan dengan adanya dua tipe soal (seri A dan B) pada permainan ular tangga kimia dapat membantu siswa untuk memantapkan konsep. Menurut Hamalik (2017)media dapat membantu siswa dalam memantapkan konsep suatu materi pembelajaran.

Setiap seri soal pada permainan ular tangga kimia memiliki tingkat kesulitan yang sama sehingga jika ada pemain yang masih kurang mengerti, maka pemain selanjutnya akan menjawab soal yang mirip dengan soal tersebut pada nomor soal yang sama dan saat pemain A menekan dadu makan akan keluar soal sesuai dengan nomor yang di tempati oleh pion, makan di saat pemain A membaca dan menjawab soal makan pemain B secara tidak langsung bisa ikut membaca dan memikirkan jawabannya. Individu yang mengulang materi secara berulang kali akan memudahkan mengingat materi yang telah dipelajari dan tidak terlupakan (relensi) (Dahar, 2011). Permainan ini dapat digunakan dalam maupun diluar pembelajaran sehingga peserta didik dapat berulang kali berlatih soal. Gambar soal paket a dan b disajikan pada Gambar 11. 
1229 Pengembangan Permainan Ular Tangga Kimia Berbasis Android Sebagai Media Pembelajaran pada Materi Senyawa Hidrokarbon di Sekolah Menengah Atas - Yurnalisa Aprilia, Iswendi

DOI: https://doi.org/10.31004/edukatif.v3i4.548

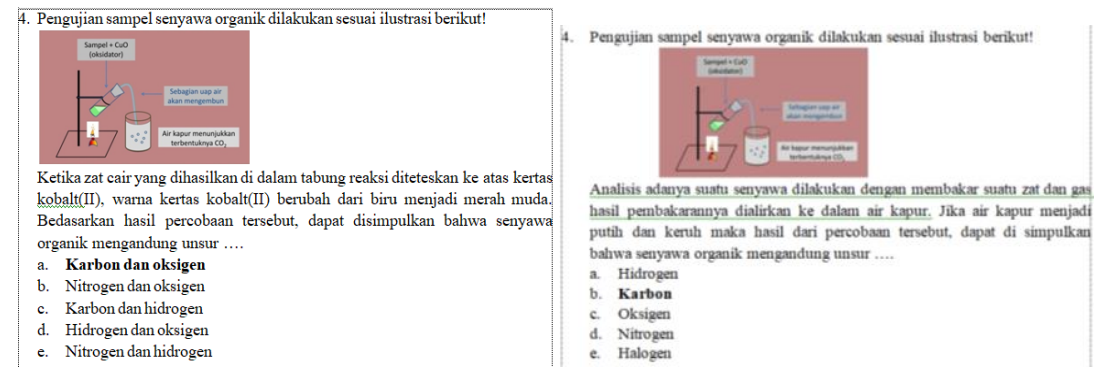

Gambar 11. soal paket a dan paket b

Penjelasan sebelumnya mengisyaratkan bahwa media pembelajaran yang di rancang telah memenuhi fungsi media pembelajaran meliputi fungsi atensi, fungsi afektif, fungsi kognitif, dan fungsi kompensatoris. Analisis data penilaian validitas dengan menggunakan aien's v 0,86 dengan kriteria valid.

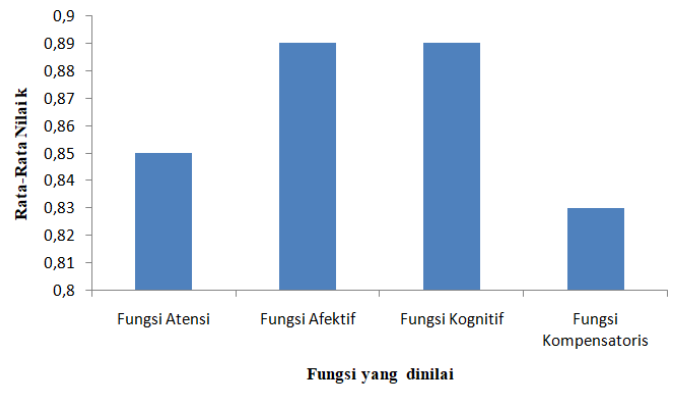

Gambar 12. Hasil uji validasi permainan ular tangga kimia berbasis android

Berdasarkan hasil uji validasi, media pembelajaran yang dikembangkan sudah sesuai dengan instrumen penilaian. Suatu produk (media pembelajaran) valid apabila dapat mengukur apa yang hendak diukur (Sukardi, 2012). Penelitian ini sebaiknya dilengkapi dengan adanya validator dari idang teknologi, sejauh ini peneliti hanya memfokuskan pada bidang penerapan materi dan desain permainan. Untuk penelitian selanjutnya dapat dilanjutkan dengan penelitin uji praktikalitas dan efektivitas permainan ular tangga berbasis android.

\section{KESIMPULAN}

Adanya permainan ular tangga kimia berbasis android sebagai media pembelajran pada materi senyawa hidrokarbon kelas XI SMA/MA dapat dikembangkan dengan menggunakan model plomp mampu untuk memantapkan pemahaman peserta didik. Aplikasi ini dapat meningkatkan aktivitas peserta didik untuk mengerjakan latihan secara mandiri dalam kelompok kecil. Aplikasi ini meminimalisir peserta didik untuk melakukan kecurangan karena setiap pemain akan mendapatkan soal yang berbeda. Aplikasi ini dapat digunakan dimana saja karena produknya yang efisien dibandingkan ular tangga manual yang membutuhkan tempat dan koordinator dalam pelaksanaanya. Permainan ular tangga kimia berbasis android sebagai media pembelajran pada materi senyawa hidrokarbon kelas XI SMA/MA yang dikembangkan terbukti sudah valid berdasarkan fungsi media.

\section{DAFTAR PUSTAKA}

Arsyad, A. (2013). Media Pembelajaran. Raja Grafindo Persada.

Dahar, R. (2011). Teori-Teori Belajar \& Pembelajaran. Erlangga. 
1230 Pengembangan Permainan Ular Tangga Kimia Berbasis Android Sebagai Media Pembelajaran pada Materi Senyawa Hidrokarbon di Sekolah Menengah Atas - Yurnalisa Aprilia, Iswendi

DOI: https://doi.org/10.31004/edukatif.v3i4.548

Daryanto. (2011). Media Pembelajaran. PT Sarana Tutorial Nurani Sejahtera.

Febriani \& Ellizar. (2019). Pengembangan Modul Termokimia Berbasis Pendekatan Saintifik Dilegkapi Dengan Pertanyaan Probing Dan Prompting Kelas Xi Tingkat SMA/MA. Ranah Research: Journal of Multidisciplinary Research and Development, 497-596.

Guterres, I. K. N. P. dkk. (2018). Pengembangan Media Pembelajaran Ular Tangga Berbasis Android Pada Pokok Bahasan Gejala Pemanasan Global untuk Pembelajaran Fisika Di SMA. Jurnal Pembelajaran Fisika, 7(1), 54-61.

Hamalik, O. (2017). Kurikulum dan Pembelajaran. Bumi Aksara.

Haryono. (2013). Pembelajaran IPA yang Menarik dan Mengasyikkan: Teori dan Aplikasi PAIKEM. Kepel Press.

Indriliza L \& Iswendi. (2019). Berbasis Chemo-Edutainment (CET) Pada Materi Sistem Koloid Terhadap Hasil Belajar Siswa Kelas XI SMAN 3 Pariaman. Edukimia Journal, 1(2).

Iswendi and R A Iswara. (2020). Pengembangan Permainan Ludo Kimia sebagai Media Pembelajaran pada Materi Interaksi Antarpartikel. Edukimia Journal, 2(1).

Iswendi, L. A. . \&. (2020). Accepted Manuscript / Postprint / Author Accepted Manuscript Validitas Permainan Ular Tangga Kimia Sebagai Media Pembelajaran Pada Materi Asam Basa Kelas XI SMA / MA The Validity of Chemical Ladder Snake Game as a Learning Media. Jurnal Edukimia, 3(1).

Murti, A. A. . (2017). Pengembangan Media Berbentuk Game Interaktif Ular Tangga untuk Meningkatkan Motivasi Belajar Siswa dalam Pelajaran Akuntansi Kelas X SMK N 1 Godean Tahun Ajaran 2016/2017. Universitas Sanata Dharma.

Musfiqon. (2012). Pengembangan Media dan Sumber Pembelajaran. Prestasi Pustakarya.

Normadana, S. (2018). Pengembangan media pembelajaran berbasis fun chemistry blog pada materi reaksi reduksi dan oksidasi kelas X 1 SMAN 1 Wedung. UIN Walisongo Semarang.

Paramita, A. (2016). Pengembangan Media Permainan Ular Tangga pada Materi Senyawa Hidrokarbon Kelas XI SMA untuk Meningkatkan Pemahaman Konsep Siswa. Unesa Journal of Chemical Education, 5(2).

Plomp, T. (2013). Educational Design Research:An Introduction, dalam AnIntroduction to Educational Research Enschede. National Institute for Curriculum Development.

Purbasari, M. R. A. D. R. I. K. J. (2014). Warna Dingin Si Pemberi Nyaman. Humaniora, 5(1), 357-366. https://doi.org/https://doi.org/10.21512/humaniora.v5i1.3034

Rahmadani, D. (2015). Penggunaan Media Permainan Ular Tangga untuk Meningkatkan Prestasi Belajar Siswa pada Pokok Bahasan Hidrokarbon di Kelas XI SMA As-shofa Pekanbaru. Universitas Riau.

Sari, Y., dkk, S. G. H. and M. M. . (2018). Pengaruh Penggunaan Media Permainan Kartu Uno Pada Materi Senyawa Hidrokarbon Terhadap Hasil Belajar Peserta didik. Vidya Karya, 33(1), 35-41.

Sudjana, N dan Rivai, R. (2011). Media Pengajaran. Sinar Baru.

Sukardi. (2012). Metodologi Penelitian Pendidikan. Bumi Aksara.

Sumadi, C. D. M. S. dan A. E. W. (2015). Pengembangan Media Game Senyawa Hidrokarbon pada Pembelajaran Kimia di SMA Batik 1 Surakarta dan SMA Batik 2 Surakarta. Jurnal Pendidikan Kimia, $4(2)$.

Yolanda, N. S., \& Iswendi, I. (2019). Pengembangan Permainan Ludo Kimia Sebagai Media Pembelajaran Pada Materi Bentuk Molekul Kelas X SMA/MA. Edukimia, 1(2), 9-14. https://doi.org/10.24036/ekj.v1.i2.a17 